\title{
THE SECURITY AND SAFETY OF MARITIME NAVIGATION THROUGH ROMANIAN MARITIME HARBORS
}

\author{
Sergiu LUPU ${ }^{1}$ \\ Andrei POCORA ${ }^{2}$ \\ Romeo BOSNEAGU ${ }^{3}$ \\ Cosmin KATONA ${ }^{4}$ \\ ${ }^{1}$ Lecturer eng. PhD, "MirceacelBatran" Naval Academy, Constanta, Romania sergiu.lupu@anmb.ro \\ ${ }^{2}$ Assistant Professor eng. PhD student, "MirceacelBatran" Naval Academy, Constanta, Romania \\ andrei.pocora@anmb.ro \\ ${ }^{3}$ Associate Professor PhD, "MirceacelBatran" Naval Academy, Constanta, Romania \\ romeo.bosneagu@anmb.ro \\ ${ }^{4}$ Asisstant Professor eng. PhD student, "MirceacelBatran" Naval Academy, Constanta, Romania \\ cosmin.katona@anmb.ro
}

\begin{abstract}
In changing times the design and build of ships has altered and the needs of the professional sailor must be adapted to meet the requirements of these modern times. The practical seaman must adapt alongside a developing hi-tech industry and be able to improve when the need arises. The increasing of the capacity of commercial ships produced a depth boundary of many ports and harbors. Constanta harbor along with the two satellite harbors, Midia and Mangalia, is at the crossroads of trade routes linking landlocked country markets of Central and Eastern Europe in the Transcaucasus region, Central Asia and the Far East.

The security and safety of navigation in the western Black Sea is in the care of civil and military departments with clearly defined prerogatives. Romanian Naval Authority through Constanta Vessel Traffic Service (VTS) supervises the coordination and control of navigation in roadstead and maritime docks by providing navigation guidance with seven lighthouses, one radio-marker, three entrance lights, three flashers and four fog signals.

This paper aims to present how the safety and security in maritime navigation on the Romanian borders and new improvements is currently assured by using an autonomous underwater vehicle (AUV). Thus, such a device could be used to monitor the seabed, to determine the hydro-acoustic diver fingerprint, underwater vehicles and surface vessels.
\end{abstract}

Key words: maritime harbors, security and safety of navigation, autonomous underwater vehicle

\section{Introduction.}

Romania through the Black Sea enjoys an important strategically position and represent a historical connection to a trade route from Europe to the Middle East.

In the Romanian concept, the Black Sea became a point of interest regarding the fact to achieve energy independence or even to decrease the imports. The Romanian maritime harbors are Constantza, Mangalia, Midia and Sulina.

Mangalia harbor is located near to the southern border with Bulgaria and operates chemicals, fertilizers, bitumen and general cargo.

Constantza maritime harbor benefitsa geographical position convenient as a strategical point of view, being at the intersection of three main transport waterway: Corridor IV (Dresden I Nuremberg - Istanbul), Corridor IX (Helsinki Alexandroupolis) and Corridor VII (Danube River) linking the North Sea to the Black Sea through the Rhine-Main-Danube corridors.
Constantza harbor has a major role in the European network of intermodal transport, favorably located at the intersection of trade routes linking landlocked country markets of Central and Eastern Europe with Transcaucasregion, Central Asia and the Far East. Near the port are located two other ports, Midia harbor and Mangalia harbor, which are part of the Romanian harbor structure and under the coordination of Maritime Ports Administration Constantza.

Midia harbor is the second largest Romanian port on the Black Sea coast. It was designed and built as former industrial harbor servicing petrochemical Midia-Năvodari. The port was designed for 7.500 DWT cargo ships up to 10.000 DWT tanker ships.

Sulina harbor is located at the mouth of Sulina Canal in the Black Sea. Sulina port has a linear composition along the east-west axis with the opening of the main Danube with urban percentage on the right. 
"Mircea cel Batran" Naval Academy Scientific Bulletin, Volume XIX - 2016 - Issue 2

The journal is indexed in: PROQUEST / DOAJ / Crossref / EBSCOhost / INDEX COPERNICUS / DRJI / OAJI I JOURNAL INDEX / I2OR / SCIENCE LIBRARY INDEX / Google Scholar / Academic Keys/ ROAD Open Access I Academic Resources / Scientific Indexing Services / SCIPIO I JIFACTOR

\section{The areas of authority responsibility}

The security and safety of navigation in the western Black Sea is in the care of civil and military departments with clearly defined prerogatives.

Western Black Sea area is monitored using the following systems:

- Radio-electronic and Observation Centre "CALLATIS" (CREO);

- The complex system of observation surveillance and traffic control in the Black Sea (SCOMAR);

- Maritime Hydrographic (DHM);

- National Institute for Marine Research and Development "GrigoreAntipa" (INCDM);

- National Institute of Research and Development of Marine Geology and Geoecology (INCD GEOECOMAR);

- Romanian Coast Station - Radio Constantza (C.N.R.N RADIONAV);

- Surveillance system for Maritime Traffic in Constantza (VTS Constanțza);

- Civil and military aviation.

a.Radio-electronic and Observation Centre "CALLATIS" (CREO)is the support structure of the Navy directly subordinated to the General Staff of the Navy designedfor waging battle in electromagnetic space and information support of Staff of the Navy and other appointees.

b. The complex system of observation surveillance and traffic control in the Black Sea (SCOMAR)is a system having as main objectives observation, surveillance and Romanian border control at Black Sea.

The system consists of the following subsystems:

- Sensor Station sub-system which includes sensors equipped with radar and optoelectronic sensors;

- Communication sub-system which permits de exchange of data in real time between de Sensor Station and Commanding and Control Centre;

- Commanding and Control Centre subsystemthat centralizes and analyzes all the information from the sensors and subsystems station from other interconnected systems;

- operational units (navy, land and air force).

SCOMAR is ready for surveillance monitoring permanent (24/7), provides an image of the surface water area, contiguous area and exclusive economic area (up to 100 nautical miles offshore). The system comes with 7 SCOMAR radar and 8 sensors.(Fig. 1.).

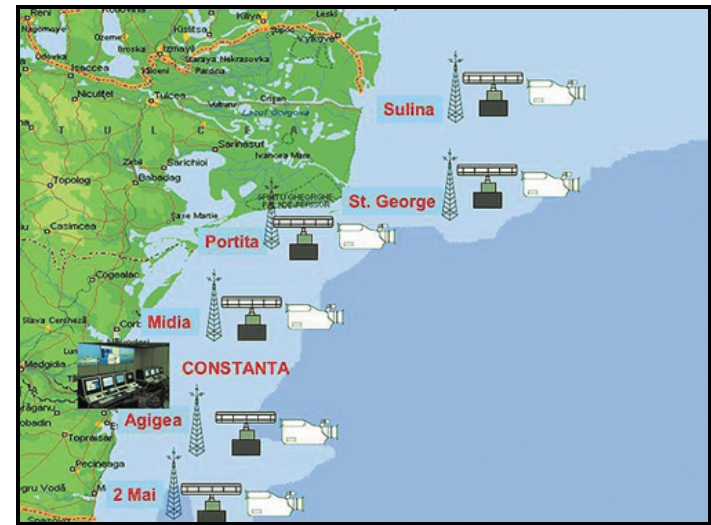

Fig. 1. SCOMAR station disposal

c. The navigation in the Romanian coastline is ensured by the Maritime Hydrographic Directorate (DHM) and is made with seven lighthouses, one radio-marker, three entrance lights, three flashers and four fog signals.

The main activities of Maritime Hydrographic Directorate are providing a permanent and secure data flow and real-time weather information,they are processing and transmit to the units the forecasts, warning, cautions, weather information and other services.

DHM transmits urgent warnings throughout the radio by NAVAREA III and local warnings that relate to the safety of navigation by the coastal radio station (frequency $500 \mathrm{KHz}$ ).

d.National Institute for Marine Research and Development "GrigoreAntipa" (INCDM) conducts research and development in areas such as physical oceanography, marine biology and marine microbiology, chemistry, biochemistry, marine engineering and technology.

e.National Research and Development Institute for Marine Geology and Geo-ecology (GeoEcoMar) is the research and development institute of national interest in geology, geophysics and geo-ecology focusing on aquatic environments, marine and river delta.

This GeoEcoMar manages an integrated regional early warning in case of geo-hazard in the Black Sea and a proper surveillance for marine seismic investigations.

Main components of early warning system are:

- Euxinus border network consists of five offshore platforms and devices equipped with sensors for monitoring hydro-meteorological factors 24/7, chemical water column and local seismicity etc (Fig. 2);

- complex station for monitoring hydrometeorological conditions and the physicalchemical parameters of sea near Mangalia harbor; 
"Mircea cel Batran" Naval Academy Scientific Bulletin, Volume XIX - 2016 - Issue 2

The journal is indexed in: PROQUEST / DOAJ / Crossref / EBSCOhost / INDEX COPERNICUS / DRJI / OAJI I JOURNAL INDEX / I2OR / SCIENCE LIBRARY INDEX / Google Scholar / Academic Keys/ ROAD Open Access I

Academic Resources / Scientific Indexing Services / SCIPIO I JIFACTOR

- GeoPontica border network consists of 18 permanent GNSS stations $24 / 7$ to monitor the movements of the Earth's crust and the evolution of meteorological parameters (Fig. 3);

- network of seismological stations (3 units in Sulina, Constantza and Manglia), which will be integrated into the national network of seismometers for monitoring seismic and strong motion (5 units in Bulgaria);

- coordination and control centers in Constantza and Varna system.

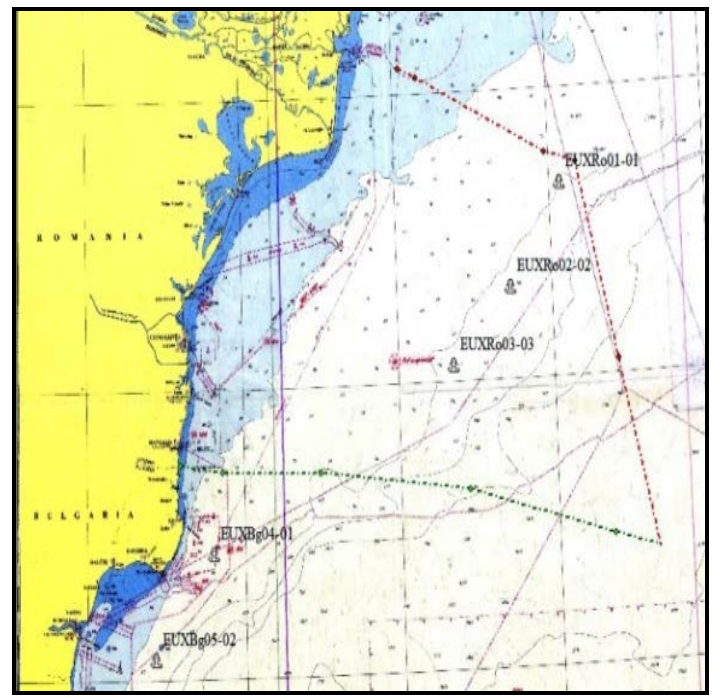

Fig. 3.Euxinus cross-border networking

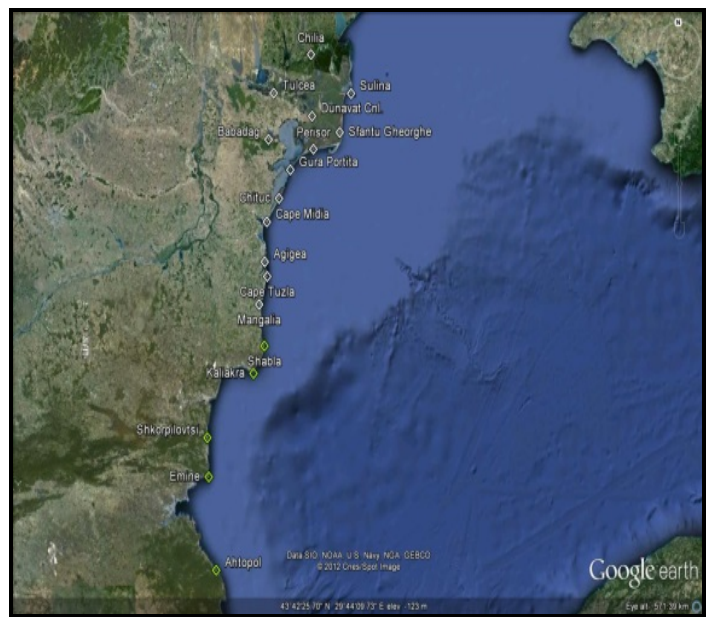

Fig. 3.GeoPontica surveillance system of Earth movements

f. Romanian Coastal station "ConstantzaRadio" (Fig. 4) - by stations A1, VHF RT (156.8 MHz/ Ch 16 (Fig. 5) and DSC (156.525 MHz/Ch 70) (Fig. 6) of land located at Sulina, Mahmudia, St. George, Enisala and Tuzla.

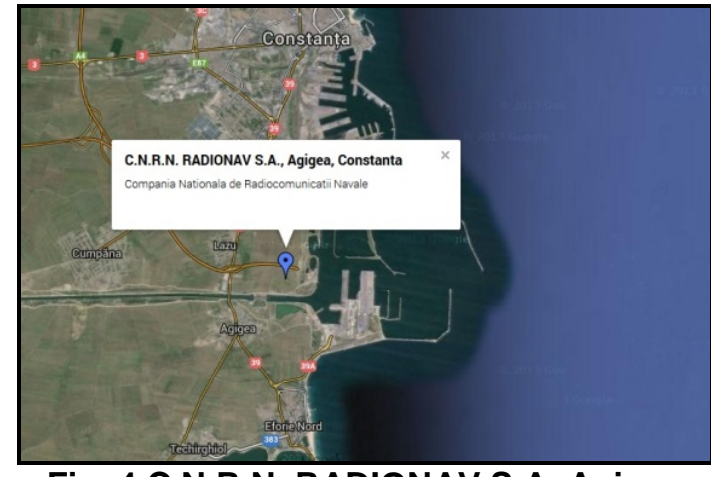

Fig. 4 C.N.R.N. RADIONAV S.A. Agigea

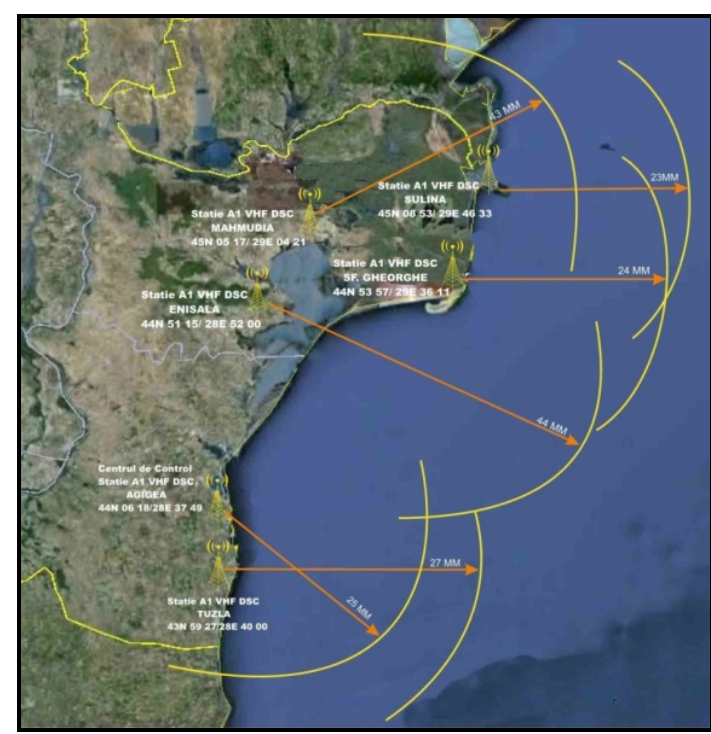

Fig. 5. A1 VHF DSC GMDSS radio communication system

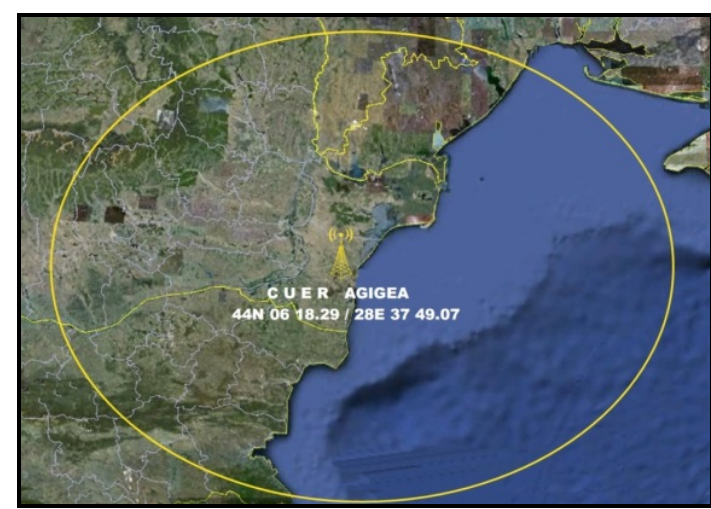

Fig. 6. A2/A3 MF/HF DSC GMDSS radio communication system

NAVTEX international service is an integrated GMDSS for transmitting and receiving messages automatically for safety navigation through NBDP (Narrow band direct printing mode, Radiotelex 70 bd FEC - F18) on $490 \mathrm{KHz}$ frequencies or 518 $\mathrm{KHz}$.

Radio Constantza transmit this information on NAVTEX (Fig. 7), information that is received directly from the Romanian designated authorities 
"Mircea cel Batran" Naval Academy Scientific Bulletin, Volume XIX - 2016 - Issue 2

The journal is indexed in: PROQUEST / DOAJ / Crossref / EBSCOhost / INDEX COPERNICUS / DRJI / OAJI / JOURNAL INDEX / I2OR / SCIENCE LIBRARY INDEX / Google Scholar / Academic Keys/ ROAD Open Access I Academic Resources / Scientific Indexing Services / SCIPIO / JIFACTOR

for safe navigation and search and rescue operation as follows:

- the navigation notices are received from Constantza Maritime Hydrographic Directorate;

- Notices for search and rescue are received from MRCC Constantza (Romanian Naval Authority);

- The notices of storm and weather reports from the Centre of Meteorology Dobrogea.

Messages are transmitted in Romanian frequencies of $490 \mathrm{kHz}$ and on $518 \mathrm{kHz}$ frequency by Radio VARNA.

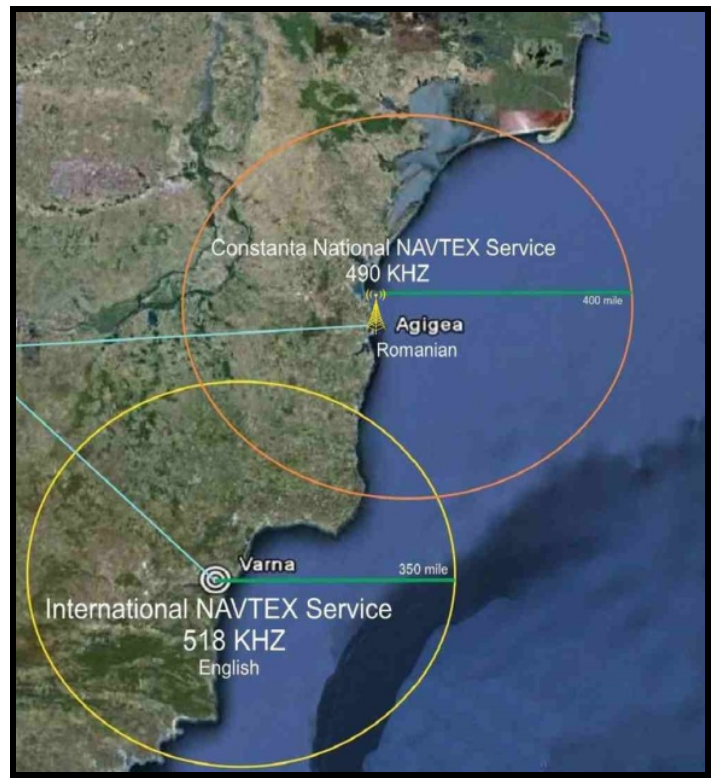

Fig. 7. NAVTEX system

Coastal Radio Station Equipment in Constantza, VHF DSC, is composed of 6 radio stations arranged at Sulina, Sf. Gheorghe, Mahmudia, Enisala, Agigea and Tuzla.

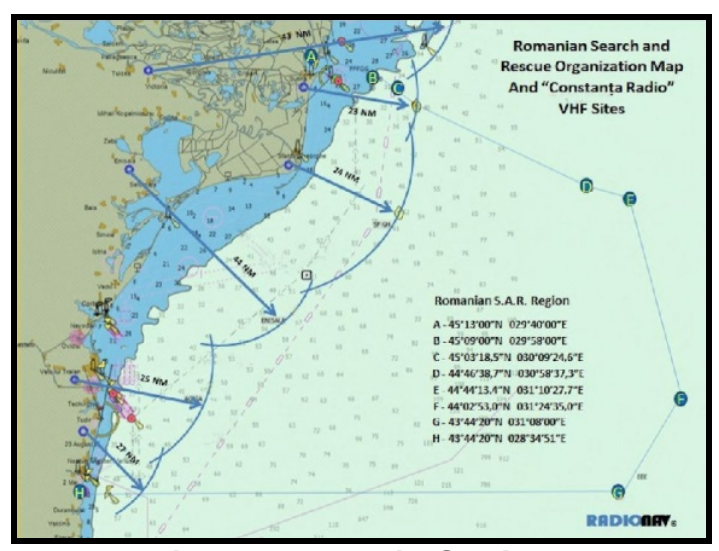

Fig. 8.VHF Radio Stations

g.The SurveillanceConstantza Maritime Traffic (VTMIS) is an integrated maritime transport management that provides acquisition, processing, management, storage, consulting and presenting data system and data from peripheral sensor.

VTS service in Constantza is subordinated to the Director of the Romanian Naval Authority and is established as a comprehensive service supervision, coordination, monitoring and management of vessel traffic that ensure optimal system operational information, navigational assistance, organization and traffic management. The system is intended to contribute to the unfolding vessel traffic safety and efficiently in the VTS area.

VTS area comprises the sea era enclosed by a circle with a radius of 12 nautical miles from the point of coordinates: latitude $44^{\circ} 10^{\prime} .2 \mathrm{~N}$ and longitude $028^{\circ} 39^{\prime} .6$ E (VTS center of Constantza). Rules of navigation in anchorage and harbor are established by the state authority in the field of maritime transport in accordance with GO 42/1997 regarding shipping and inland waterways, as amended and/or further additions.

Supervision, coordination and control of navigation in anchorage zones and sea ports is exercised by the Romanian Naval Authority.

Border Police, Coast Guard and Maritime transport Police Service Constantza have authority to take custody, under the law, of found or abandoned goods in the traffic control area or in the Romanian border.

All ship types, regardless of all flags that enter into anchorage area or harbor are obliged to comply with the provisions on entry, navigation in national waters, cargo operation and leaving the harbor provided by GO 42/1997 regarding shipping and inland waterways.

In harbors is adopted the international maritime system "A", made in accordance with the International Association of Lighthouse Authorities (IALA). Stationing and waterways become an issue for the harbor administration after approval by the Romanian Naval Authority to access in the port.

Every vessel bound for a Romanian harbor is obliged to make known his on-coming to the VTS or to the Romanian Naval Authority, immediately after reaching the limit range of traffic surveillance. The communication is performed by radiotelephone in VHF on channel 16 and/or 67.

Since the ship enters into the traffic controlarea, ships are required to comply with VTS or Romanian Naval Authority.

VTS provisions or Romanian Naval Authority precedence over any other provisions and mandatory for all ships in the traffic control.

Throughout the stationary in the anchorage area and carrying out manoeuvers and for 30 minutes before and after finishing, ships must ensure a permanent communication with VTS or port authority. 


\section{"Mircea cel Batran" Naval Academy Scientific Bulletin, Volume XIX - 2016 - Issue 2 The journal is indexed in: PROQUEST / DOAJ / Crossref / EBSCOhost / INDEX COPERNICUS / DRJI / OAJI I JOURNAL INDEX / I2OR / SCIENCE LIBRARY INDEX / Google Scholar / Academic Keys/ ROAD Open Access I Academic Resources / Scientific Indexing Services / SCIPIO / JIFACTOR}

Manoeuvers ships of any category in harbor, shall be made only with the approval of the Romanian Naval Authority.

In the commercial maritime harbor, Constantza, Midia and Mangalia, ships manoeuvers are allowed at any time, day and night, except for periods of time communicated by VTS or RNA (Romanian Naval Authority). The Constantza harbor is prohibited at night manoeuvers entry/ exit of vessels with a draft greater than 16 meters at berth $80,81,82$ when at berth 79 is operating an oil tanker.

Port Authority, directly or through VTS may suspend manoeuvers when the wind force exceeds 7 Beaufort Scale Force (BFS) in Constantza or 7 Beaufort Scale Force (BFS) in Midia and Mangalia or when the visibility affects the safety of the manoeuvers.

Until the ship gets the permission to moor, the ship will anchor corresponding to its category and in the goods being transported.

The ships are required upon entering the harbor to use the traffic separation scheme.

Any manoeuver for anchoring, change of anchorage area or departure from the anchor, entry or exit port will be made only after acquiring the approval of VTS or Romanian Naval Authority. For mooring in the Romanian harbors the representatives will deliver the mooring permission for berthing.

The permission for departure is released with the condition that the vessel should acquire the approval from all relevant authorities, to submit the permission papers for berthing in the harbor with all necessaries for loading/unloading goods and a copy of the manifest of goods checked by customs

Pilotage represents a safety service and is compulsory in harbors. An exception are the following categories of ships with a Romanian flag: surveillance ships, technical vessels, sea fishing vessels, crafts and military vessels.

Towing service for ships in Constantza, Midia and Mangalia harbor is ensured by the naval administration through specialized economic operators authorized under the law and under the service contract imposed by the framework agreement.

\section{The security and safety of maritime navigation}

Vessel safety is influenced by a great many individuals:

- the master and crew, who are ultimately responsible for handling the vessel and who know its capabilities and limitations;

- system operators, who provide navigation information to vessels;
- marine pilots, who need accurate and timely information on local harbors or waterways;

- VTS personnel, who must make decisions based on the conditions and other traffic in the area;

- local service providers, such as tug masters and shipping agents;

- seafarer on other vessels in the area.

The Port Marine Safety Code requires that all ports must base their management of marine operations on a formal assessment of the hazards and risks to navigation within the port. Furthermore, port authorities must maintain a formal navigational Safety Management System (SMS) developed from that risk assessment.A Navigation Safety Management System should be informed by, and based upon a formal strategic navigation risk assessment of the port's marine activities (routine and non-routine), which is a documented, structured and systematic process comprising.

The increasing of the capacity of commercial ships produced a depth boundary of many ports and harbors.

When a ship is passing under a bridge or moving through a channel, it can be a pretty tight fit. To avoid collisions and ensure safe passage, mariners rely on Romanian Naval Authority (RNA)positioning information.

All agents from Constantza and Midia harbor are obliged to comply with all the regulations on maritime security introduced by the International Maritime Organization - ISPS Code.

From the category of risk factors to the objectives of strategic importance we can identify:

- human nature;

- natural phenomena.

From the category of human nature we can identify:

- human infiltration (frogmen, submersibles, and suicide teams);

- delivery of chemical, biological, radiological, nuclear, and high yield;

- explosive (CBRNE) weapons by commercial vessel;

- vessels themselves as weapons;

- terrorismand improvised explosive devices.

From the category of natural phenomena we can identify:

- river deposits,

- embankment;

- marine currents;

The security area which include personnel access and transport is the responsibility of the Ministry of Transport and Infrastructure through the Romanian Naval Authority and CNn APM SA. Authorized access is the responsibility of the 
"Mircea cel Batran" Naval Academy Scientific Bulletin, Volume XIX - 2016 - Issue 2 The journal is indexed in: PROQUEST / DOAJ / Crossref / EBSCOhost / INDEX COPERNICUS / DRJI / OAJI / JOURNAL INDEX / I2OR / SCIENCE LIBRARY INDEX / Google Scholar / Academic Keys/ ROAD Open Access I Academic Resources / Scientific Indexing Services / SCIPIO / JIFACTOR

Ministry of Internal Affairs by the Border Police. The underwater safety is the Navy responsibility. To monitor the seabed, to determine the hydroacoustic diver fingerprint, underwater vehicles and surface vessels could be used an autonomous underwater vehicle (AUV).

In order to achieve the goal of ensuring security and safety of navigation through Romanian Harbors, Research Centre of the Navy is developing the project "System for detection, location, tracking and identification of risks factors against objectives in the area of seaside (SIROLC)" through a national program where the authors are partners.

The final result of the research is the design of a system for hydro-acoustic detection, tracking, tracing and identification of risk factors to the objectives of strategic importance in coastal areas.

The AUV characteristics:

- class: „man - portable”, 20 - 25 kg;

- autonomy: 8 hours at v = 2.5 knot;

- maxim speed: 8 knot;

- maxim depth: 100 m;

- navigation:

-at surface: GPS

- sensors: compass, depth, altitude sensor (rolling and pitching etc.), sonar with side scan;

- communication: at surface-WiFi;

- software: planning mission, analysis data and sonar images overlap.

Side scanning provides angled distance (R) 150 $\mathrm{m}$ to both sides at a height $(\mathrm{H})$ of $15 \mathrm{~m}$ but below the AUV involves a strip width (I) of $15 \mathrm{~m}$ uncovered.

The recommended altitude for identification is $\mathrm{H}=$ $10 \mathrm{~m}$ and for classification is $\mathrm{H}=2 \div 5 \mathrm{~m}$.

The resolution on the perpendicular trajectory is maximum $2 \mathrm{~cm}$ and approximately to the path 1 degree. A position correction is recommended before entering the lift pass through the surface point after GPS.
For this paper the authors conducted a study concerningthe time needed to scan Romanian ports with an AUV. For this study was used electronic map NAVI-SAILOR 3000 (fig. 9) using that they were determined the number of courses required coverage of each port depending on its configuration, total distance and total time (Tab. 1).

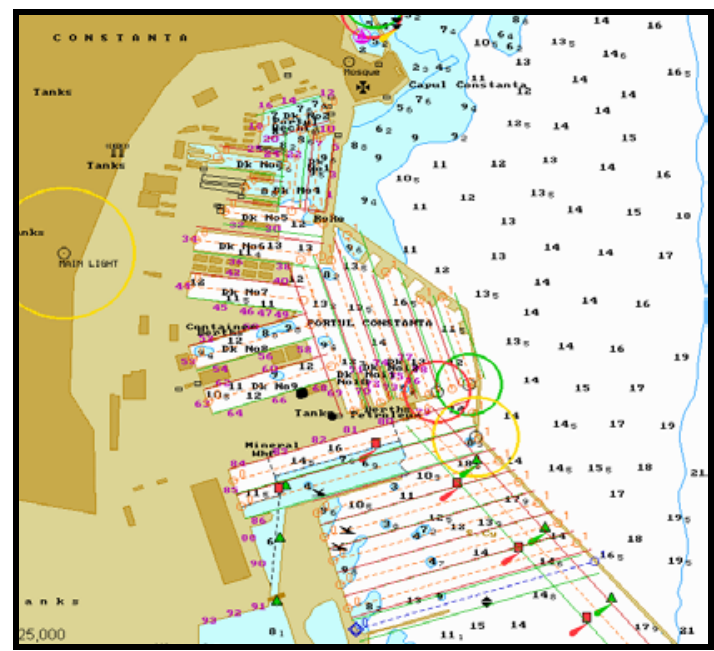

Fig. 9. AUV covering Port of Constantza

Table 1. Total distance and time for scaning maritime romanian harbours

\begin{tabular}{|l|c|c|c|c|}
\hline \multirow{2}{*}{ Harbour } & \multirow{2}{*}{$\begin{array}{c}\text { No. of } \\
\text { courses }\end{array}$} & $\begin{array}{c}\text { Total } \\
\text { distance } \\
{[\mathrm{nm}]}\end{array}$ & \multicolumn{2}{|c|}{$\begin{array}{c}\text { Total time } \\
\text { for speed }\end{array}$} \\
\cline { 4 - 5 } & & $\begin{array}{c}2 \\
\mathrm{knts}\end{array}$ & $\begin{array}{c}2,5 \\
\mathrm{knts}\end{array}$ \\
\hline Mangalia & 14 & 9 & $4^{\mathrm{h}} 30^{\mathrm{m}}$ & $3^{\mathrm{h}} 36^{\mathrm{m}}$ \\
\hline Constantza & 50 & 38 & $19^{\mathrm{h}}$ & $15^{\mathrm{h}} 12^{\mathrm{m}}$ \\
\hline Midia & 22 & 20,8 & $10^{\mathrm{h}} 24^{\mathrm{m}}$ & $8^{\mathrm{h}} 20^{\mathrm{m}}$ \\
\hline Sulina & 2 & 14,5 & $7^{\mathrm{h}} 15^{\mathrm{m}}$ & $6^{\mathrm{h}} 28^{\mathrm{m}}$ \\
\hline
\end{tabular}

\section{CONCLUSIONS}

The insurance of safety and security of maritime navigation through Romanian harbours represent the desideratum of our government.

For this purpose, several civil and military departments work together with clearly defined prerogatives.

The security of underwater port infrastructure is the exclusive consideration of Navy.

Through the project: System for detection, location, tracking and identification of risk factors against objectives in the coastal areas (SIROLC), from National Program for research PN II, from 2014 to 2017 , the Research Center of the Navy wants to design a system for hydro-acoustic detection, tracking, tracing and identification of risk factors to the objectives of strategic importance in coastal areas.

According to the characteristics of this AUV, the time required for scanning of Romanian ports is relatively low. Thus, using a single AUV is sufficient to carry out periodic scanning access passes, berths and port basins. 
"Mircea cel Batran" Naval Academy Scientific Bulletin, Volume XIX - 2016 - Issue 2

The journal is indexed in: PROQUEST / DOAJ / Crossref / EBSCOhost / INDEX COPERNICUS / DRJI / OAJI / JOURNAL INDEX / I2OR / SCIENCE LIBRARY INDEX / Google Scholar / Academic Keys/ ROAD Open Access I Academic Resources / Scientific Indexing Services / SCIPIO / JIFACTOR

\section{BIBLIOGRAPHY}

[1] www.navy.ro

[2] www.politiadefrontiera.ro/securizare/scomar

[3] www.dhmfn.ro

[4] www.rmri.ro

[5] www.geohazard-blacksea.eu

[6] www. radionav.ro

[7] www.rna.ro

[8] Transas Ltd. NAVI-SAILOR 3000

[9] Pricop M. et al., (2015), Passive acoustic underwater noise measurements in Constanta port area, "Mircea cel Batran" Naval Academy Scientific Bulletin, Volume XVIII, Issue 2, p 64-69.

[10] Pricop M et al. (2010), Underwater Radiated Noise of Ship's Machinery in Shallow Water, WSEAS Advanced manufacturing engineering, quality and production systems, Constanta Maritime University, 71-76. [11] Toma A. et al., (2012), Intercommunication between NATO and shipping industry for maritime security, Scientific Bulletin of Naval Academy Vol. XV/ Issue no. 2-2012, pag. 71-73, Published by "Mircea cel Batran" Naval Academy Press, ISSN 1454-864X (Category B/CNCS). 